\title{
IMPLEMENTASI MODEL PEMBELAJARAN KOOPERATIF TIPE STAD DALAM MATA KULIAH STATISTIK DASAR PADA PROGRAM STUDI PENDIDIKAN BIOLOGI
}

\author{
Ahmad Yani ${ }^{1}$ dan Kurnia Ningsih ${ }^{2 *}$ \\ ${ }^{1}$ Dosen Pendidikan Matematika FKIP Universitas Tanjungpura, Pontianak \\ ${ }^{2}$ Dosen Pendidikan Biologi FKIP Universitas Tanjungpura, Pontianak \\ *E-mail: nia_untan@yahoo.com
}

\begin{abstract}
This aims this study is to obtain objective information about the learning outcome after implementation of type STAD cooperative learning model on basic statistics course in third semester of PAPK Program in Biology Education. In addition, this study develop students's ability to understand in working together to solve and resolve the problem. The samples of study were third semester students in PAPK program who follow the Basic Statistics course in Biology Education Departement of PMIPA FKIP Untan 2016-2017. Implementation in the data presentation focused on the subject matter, size and placement of the central symptoms.The data collection conducted in providing achievement test after being given treatment. Form of test is essay with 2 questions which consist of 13 questions. The results showed if the type STAD cooperative learning model is one model that could improve student's outcome on the subject presentation of the data, the size of the placement and symptoms in statistics basic course.
\end{abstract}

Keywords: STAD cooperative learning model

Pendidikan Nasional berfungsi mengembangkan kemampuan dan membentuk watak serta peradaban bangsa yang bermartabat dalam rangka mencerdaskan kehidupan bangsa. Pendidikan nasional bertujuan untuk berkembangnya potensi peserta didik agar menjadi manusia yang beriman dan bertaqwa kepada Tuhan Yang Maha Esa, berakhlak mulia, sehat, cakap, kritis, kreatif, mandiri, dan menjadi warga Negara yang demokratis serta bertanggungjawab. Soedjadi (2004) bahwa pendidikan matematika memiliki dua tujuan besar yang meliputi; (1) tujuan yang bersifat formal, yang memberi tekanan pada penataan nalar anak serta pembentukan pribadi anak, dan (2) tujuan yang bersifat material yang memberi tekanan pada penerapan matematika serta kemampuan memecahkan masalah matematika.

Pembelajaran matematika yang berorientasi pada tujuan tersebut, pelaksanaannya di depan kelas tidak cukup membekali siswa dengan berbagai pengetahuan matematika tetapi lebih dari itu diperlukan adanya upaya nyata yang dilakukan secara intensif untuk menumbuh kembangkan kemampuan memperoleh pengetahuan matematika dengan menemukan sendiri maupun secara berkolaborasi serta 
kemampuan menerapkannya dalam situasi masyarakat modern. Sumarmo (2000) menyatakan bahwa pembelajaran matematika di semua jenjang pendidikan meliputi: (1) belajar memahami (learning to know),(2) belajar melaksanakan (learning to do), (3) belajar menjadi diri sendiri (learning to be), dan (4) belajar hidup dalam kebersamaan yang damai dan harmonis (learning to live together in peace and harmony). Empat pilar ini sesuai dengan yang telah ditetapkan pada akhir abad 21 oleh UNESCO, organisasi pendidikan dunia. Keempat pilar tersebut bukan merupakan suatu urutan, melainkan saling melengkapi satu dengan yang lainnya, sehingga dalam pembelajaran di tiap jenjang pendidikan guru dapat menciptakan suasana belajar yang memuat keempat pilar tersebut secara bersama-sama dan seimbang.

$$
\text { Guru diharapkan dapat }
$$
menyajikan materi pelajaran yang mudah dipahami atau dimengerti, untuk itu dibutuhkan variasi-variasi dalam proses pembelajaran. Variasivariasi dalam proses pembelajaran diharapkan siswa mudah memahami materi yang disampaikan dan tidak merasa jenuh atau bosan. Untuk membuat siswa mudah memahami dan tidak merasa jenuh atau bosan dalam proses pembelajaran dibutuhkan model pembelajaran yang tepat.

Menurut Trianto (2007:1), model pembelajaran adalah suatu perencanaan atau suatu pola yang digunakan sebagai pedoman dalam merencanakan pembelajaran di kelas atau pembelajaran tutorial. Sebelum guru mengajar maka harus dipersiapkan perencanaan atau pola yang digunakan dalam merencanakan pembelajaran. Untuk menerapkan suatu model pembelajaran, guru harus menguasai berbagai model pembelajaran yang sesuai dengan materi pelajaran, keadaan siswa, serta mengedepankan model pembelajaran yang berorientasi pada siswa.

Pengajar (guru/dosen) dituntut untuk menguasai model pembelajaran yang sesuai dengan karakteristik materi pelajaran, keadaan mahasiswa/siswa, lingkungan sekolah, serta mengedepankan proses pembelajaran yang berpusat pada siswa. Pengajar dituntut terampil dalam pengelolaan kelas, sehingga model pembelajaran yang digunakan dalam proses pembelajaran memberikan hasil belajar yang bermakna.

Trianto (2007:33) menyatakan bahwa pembelajaran kooperatif (Cooperative Learning) adalah pendekatan pembelajaran yang berfokus pada penggunaan kelompok kecil siswa untuk bekerja sama dalam memaksimalkan kondisi belajar untuk mencapai tujuan belajar. Slavin (2010:4), pembelajaran kooperatif adalah merujuk pada berbagai macam metode pembelajaran di mana para siswa bekerja dalam kelompokkelompok kecil untuk saling membantu satu sama lainnya dalam mempelajari materi pelajaran. Model pembelajaran yang berorientasi pada siswa adalah model pembelajaran Kooperatif, sedangkan gurunya adalah sebagai fasilitator. Dengan demikian, pembelajaran kooperatif menekankan pada interaksi sosial, dengan tujuan agar siswa bersamasama mencapai tujuan bersama.

Rusman

(2011:207)

menyatakan bahwa karakteristik atau 
ciri-ciri pembelajaran kooperatif meliputi: (1) Pembelajaran secara tim, (2) Didasarkan pada manajemen kooperatif, (3) Kemauan untuk bekerja sama, (4) Keterampilan kerja. Rusman (2011: 208) menyatakan bahwa unsur-unsur pembelajaran kooperatif meliputi: (a) siswa dalam kelompoknya haruslah beranggapan bahwa mereka sehidup sepenanggungan bersama, (b) siswa bertanggung jawab atas segala sesuatu di dalam kelompoknya, seperti milik mereka sendiri, (c) siswa haruslah melihat bahwa semua anggota di dalam kelompoknya, memiliki tujuan yang sama, (d) siswa haruslah membagi tugas dan tanggung jawab yang sama di anatar anggota kelompoknya, (e) siswa yang akan dikenakan evaluasi atau diberikan hadiah/penghargaan yang akan dikenakan untuk semua anggota kelompok, (f) siswa berbagi kepemimpinan dan mereka membutuhkan ketrampilan untuk belajar bersama selama proses pembelajarnya, (g) siswa diminta mempertanggungjawabkan secara individual materi yang ditangani dalam kelompok kooperatif.

Lie (2010:32) menyatakan bahwa untuk mencapai hasil yang maksimal, lima unsur model pembelajaran gotong royong harus diterapkan yaitu: (a) saling ketergantungan positif, (b) tanggung jawab perorangan, artinya prosedur model cooperative learning, setiap siswa akan merasa bertanggung jawab untuk melakukan yang terbaik, (c) tatap muka, artinya kegiatan interaksi akan memberikan para pembelajar untuk membentuk sinergi yang menguntungkan semua anggota, (d) komunikasi antar anggota, artinya keberhasilan suatu kelompok juga bergantung pada kesediaan para anggotanya untuk saling mendengarkan dan kemampuan untuk mengutarakan pendapat, dan (e) evaluasi proses kelompok, artinya waktu evaluasi tidak perlu diadakan setiap kali ada kerja kelompok.

Berdasarkan pendapat di atas, maka diharapkan unsur-unsur yang di dalam pembelajaran kooperatif meliputi: (a) kepedulian antar sesama, kebersamaan (kolaboratif), tenggang rasa, dan menciptakan komunikasi anggota kelompok, dan (b) sikap tanggung jawab, disiplin, jujur antar anggota kelompok. Hal ini didukung oleh Rusman (2011: 211) menyatakan bahwa terdapat enam langkah utama atau tahapan di dalam model pembelajaran kooperatif. Langkahlangkah dalam pembelajaran kooperatif dapat dilihat pada Tabel 1. Menurut Slavin (2010: 4), pembelajaran kooperatif merujuk pada berbagai macam metode pembelajaran dimana para siswa bekerja dalam kelompokkelompok kecil untuk saling membantu satu sama lainnya dalam mempelajari materi. Ini berarti diharapkan siswa dalam satu kelompok untuk saling membantu, berdiskusi, dan beragumentasi untuk mengasah pengetahuan yang mereka miliki pada saat itu.

Pembelajaran kooperatif memiliki banyak tipe, salah satunya model pembelajaran kooperatif tipe STAD. Model pembelajaran kooperatif tipe STAD, siswa dibagi ke dalam beberapa kelompok, yang terdiri dari kelompok yang heterogen. Arti heterogen adalah gender, suku, dan tingkat kemampuan. Dalam satu kelompok belajar terdiri atas 4-5 orang siswa yang mewakili seluruh bagian 
kelas dalam hal kemampuan. Dengan penerapan model pembelajaran kooperatif tipe STAD dapat mengatasi masalah tersebut dan dapat meningkatkan hasil belajar siswa. Penerapan model kooperatif tipe STAD adalah metode ini paling sesuai untuk mengajarkan pada bidang studi yang sudah terdefinisikan dengan jelas, seperti matematika, berhitung dan konsep-konsep ilmu pengetahuan ilmiah (Slavin, 2010: 12).

Tabel 1. Langkah-langkah Model Pembelajaran Kooperatif

\begin{tabular}{|c|c|}
\hline TAHAP & TINGKAH LAKU GARU \\
\hline $\begin{array}{l}\text { Tahap } 1 \\
\text { Menyampaikan tujuan dan } \\
\text { memotivasi siswa }\end{array}$ & $\begin{array}{l}\text { Guru menyampaikan tujuan pelajaran yang akan } \\
\text { dicapai pada kegiatan pelajaran dan menekankan } \\
\text { pentingnya topik yang akan dipelajari dan } \\
\text { memotivasi siswa belajar. }\end{array}$ \\
\hline $\begin{array}{l}\text { Tahap } 2 \\
\text { Menyajikan informasi }\end{array}$ & $\begin{array}{l}\text { Guru menyajikan informasi atau materi kepada } \\
\text { siswa dengan jalan demonstrasi atau melalui } \\
\text { bahan bacaan }\end{array}$ \\
\hline $\begin{array}{l}\text { Tahap 3 } \\
\text { Mengorganisasikan siswa } \\
\text { kedalam kelompok- } \\
\text { kelompok belajar }\end{array}$ & $\begin{array}{l}\text { Guru menjelaskan kepada siswa bagaimana } \\
\text { caranya membentuk kelompok belajar dan } \\
\text { membimbing setiap kelompok agar melakukan } \\
\text { transisi secara efektif dan efisien. }\end{array}$ \\
\hline $\begin{array}{l}\text { Tahap } 4 \\
\text { Membimbing kelompok } \\
\text { bekerja dan belajar }\end{array}$ & $\begin{array}{l}\text { Guru membimbing kelompok-kelompok belajar } \\
\text { pada saat mereka mengejakan tugas mereka. }\end{array}$ \\
\hline $\begin{array}{l}\text { Tahap } 5 \\
\text { Evaluasi }\end{array}$ & $\begin{array}{l}\text { Guru mengevaluasi hasil belajar tentang materi } \\
\text { yang telah dipelajari atau masing kelompok } \\
\text { mempresentasikan hasil kerjanya }\end{array}$ \\
\hline $\begin{array}{l}\text { Tahap } 6 \\
\text { Memberikan penghargaan }\end{array}$ & $\begin{array}{l}\text { Guru mencari cara-cara untuk menghargai baik } \\
\text { upaya maupun hasil belajar individu dan } \\
\text { kelompok. }\end{array}$ \\
\hline
\end{tabular}

(Rusman, 2011: 211)

Model pembelajaran kooperatif tipe STAD tim terdiri dari empat atau lima siswa yang mewakili seluruh bagian dari kelas dalam hal kinerja akademik, jenis kelamin, ras dan etnisitas (Slavin, 2005: 144). Dengan demikian pembelajaran kooperatif tipe STAD mengedepankan perbedaan dalam pembelajaran kelompok.

Menurut Rusman (2011: 215), Langkah-langkah model pembelajaran kooperatif Tipe STAD meliputi: (1) Pencapaian tujuan dan motivasi. Menyampaikan tujuan pembelajaran yang ingin dicapai pada pembelajaran tersebut dan memotivasi mahasiswa untuk belajar. (2)Pembagian kelompok. Mahasiswa dibagi ke dalam beberapa kelompok, dimana setiap kelompoknya terdiri dari 4-5 mahasiswa yang memprioritaskan heterogenitas (keragaman) kelas dalam prestasi akademik, gender/jenis kelamin, ras atau etnik. (3) Presentasi dosen. Dosen menyampaikan materi perkuliahan dan tujuan pembelajaran yang ingin dicapai, pentingnya pokok bahasan dipelajari. Dosen memberi 
motivasi mahasiswa agar dapat belajar dengan aktif dan kreatif. Kemudian dalam proses pembelajaran harus menggunakan media pembelajaran. (4) Kegiatan belajar dan tim (kerja tim). Mahasiswa belajar dalam kelompok yang telah dibentuk. Dosen menyiapkan lembar kerja sebagai pedoman bagi kerja kelompok, sehingga semua anggota menguasai dan masing-masing memberikan kontribusi. Selama tim kerja, dosen melakukan pengamatan, memberikan bimbingan, dorongan dan bantuan yang diperlukan. Kerja tim ini merupakan ciri terpenting dari STAD. (5) Kuis (evaluasi). Dosen mengevaluasi hasil belajar melalui pemberian kuis, penilaian terhadap presentasi hasil kerja kelompok mahasiswa diberikan kursi secara individual. dosen menetapkan skor untuk setiap soal, misalnya 10 dan seterusnya dengan tingkat kesulitan. (6) Penghargaan presentasi tim. Setelah pelaksanaan kuis, dosen memeriksa hasil kerja siswa dan diberikan angka dengan rentang 0100. Pemberian penghargaan atas keberhasilan kelompok dapat dilakukan oleh dosen dengan melakukan tahapan-tahapan.

Dipilihnya materi Penyajian Data dan Ukuran Penempatan dan Gejala Pusat adalah kerena penyajian data dengan tabel, diagram dapat dilanjutkan dengan ukuran penemapatan dan gejala pusat yang memungkinkan dapat dilakukan dengan bersama-sama. Diharapkan dengan penerapan model kooperatif tipe STAD dapat mengatasi masalah dan dapat meningkatkan hasil belajar mahasiswa. Penelitian ini untuk meningkatkan hasil belajar dengan menggunakan model pembelajaran kooperatif tipe STAD materi penyajian data, ukuran penempatan dan gejala pusat pada mata kuliah statistik dasar mahasiswa semester III Program PAPK program studi pendidikan biologi.

\section{METODE}

Metode yang digunakan dalam penelitian ini adalah metode eksperimen. Menurut Sugiyono (2011) tujuan dari penelitian eksperimen adalah untuk menyelidiki hubungan sebab akibat dengan cara memberi perlakuan pada kelompok eksperimen. Hal ini dikarenakan yang menjadi objek penelitian adalah mahasiswa. Artinya ada variabel yang kondisinya tidak mungkin dibuat sama, diantaranya adalah tingkat kecerdasan mahasiswa, latar belakang, atau kondisi sosial ekonomi mahasiswa. Oleh sebab itu, penelitian ini berbentuk eksperimen semu (quasy ekspeimental design) dengan rancangan one group pretest postets design. Sampel dalam penelitian ini adalah mahasiswa semester III program Percepatan Angka Partisipasi Kasar (PAPK) yang mengambil mata kuliah Statistik Dasar berjumlah 30 orang. Instrumen yang digunakan untuk memperoleh data dalam penelitian adalah soal esai sebanyak 2 soal dengan 13 pertanyan yang harus dijawab dengan benar. Soal yang dibuat meliputi materi : rata-rata, standar deviasi, koefisien variansi, quartil, persentil, derajat kemiringan dan derajat keruncingan. Masingmasing soal memuat indikator yang menunjukkan kemampuan menghitung dan mengunakan rumus yang di pelajari. Penilaian hasil belajar diberikan dengan memberikan 
skor sesuai dengan ketentuan jika benar diberikan skor 1 dan salah diberikan skor 0 .

Data diperoleh adalah skor hasil belajar mahasiswa sebelum dan sesudah diberikan perlakukan dengan menggunakan model pembelajaran kooperatif tipe STAD pada materi penyajian data, ukuran penempatan dan gejala pusat. Pengelohan data untuk melihat perbedaan dan pengaruhkemampuan menuliskan definisi dan teorema dalam bentuk simbolik mahasiswa dihitung dengan menggunakan uji t dan effect size dari Sugiyono (2011).

\section{HASIL DAN PEMBAHASAN}

Sebelum menguji hipotesis maka dilakukan uji normalitas. Menurut Sugiyono (2011) hal ini dilakukan untuk menentukan statistik yang digunakan pengujian hipotesis. Untuk menguji kenormalan data dari sampel digunakan uji Chi-Kuadrat. Berikut merupakan Tabel hasil uji normalitas:

Tabel 2. Hasil Uji Normalitas

\begin{tabular}{ccc}
\hline Statistik & Pretes & Postes \\
\hline & 34,10 & 75,54 \\
$S \boldsymbol{D}$ & 8,12 & 11,51 \\
2 & & 11,34 \\
${ }^{\text {tabel }}$ & & 9,43 \\
hitung & & \\
\hline
\end{tabular}

Berdasarkan hasil perhitungan uji normalitas, diperoleh nilai ${ }^{2}$ hitung dari postes adalah 9,43 sedangkan nilai ${ }^{2}$ tabel adalah 11,34 dengan $\alpha=$ 0,01 . Dengan demikian dapat disimpulkan data postes berdistribusi normal. Karena data dari pretes dan postes berdistribusi normal, maka akan dilanjutkan dengan uji t. Dari perhitungan diperoleh hasil uji $t$ dapat dilihat pada tabel 3 sebagai berikut.

Tabel 3. Rekapitulasi Hasil uji t

\begin{tabular}{cc}
\hline Df & 29 \\
\hline $\mathrm{Md}$ & 57,4 \\
\hline $\mathrm{t}_{\text {hitung }}$ & 26,5 \\
\hline $\mathrm{t}_{\text {tabel }}$ & 2,75 \\
\hline
\end{tabular}

Berdasarkan hasil perhitungan dengan menggunakan $\alpha=0,05$, dan $\mathrm{t}_{\text {hitung }}$ dengan nilai 26,5 sedangkan $t_{\text {tabel }}$ nilai 2,75, maka disimpulkan bahwa terdapat perbedaan hasil belajar oleh mahasiswa sebelum dan sesudah dilakukan pembelajaran dengan model kooperatif tipe STAD pada materi penyajian data, ukuran penempatan dan gejala pusat mata kuliah statistik dasar program studi pendidikan biologi mahasiswa semester 3 PAPK.

Untuk mengetahui berapa besar kontribusi model pembelajaran kooperatif tipe STAD pada mahasiswa semester 3 program studi pendidikan biologi pada mata kuliah statistik dasar dihitung menggunakan effect size. Dari data diketahui bahwa skor rata-rata pretest sebesar 34,10 dengan standar deviasi 8,12. Sedangkan skor rata-rata postes sebesar 75,54 dengan standar deviasi 11,51. Dengan demikian diperoleh effect size sebesar 3,6 termasuk kategori tinggi. Dengan demikian dapat disimpulkan bahwa penerapan model pembelajaran kooperatif tipe STAD terhadap hasil belajar mahasiswa pada mata kuliah statistik dasar memberikan pengaruh yang tinggi.

Penelitian ini adalah untuk mengetahui apakah terdapat peningkatan hasil belajar pada materi penyajian data, ukuran penempatan 
dan gejala pusat mata kuliah statistik dasar setelah diajarkan melalui model pembelajaran kooperatif tipe STAD pada mata kuliah statistik dasar. Hasil penelitian meliputi kemampuan menyajikan data, ukuran menempatan dan ukuran gejala pusat. Pretest dan postest yang diberikan berupa esai sebanyak 2 soal esai dengan 13 pertanyan yang harus dijawab dengan benar. Soal-soal meliputi materi : rata-rata, standar deviasi, koefisien variansi, quartil, persentil, derajat kemiringan dan derajat keruncingan. Masing-masing soal memuat indikator yang menunjukkan kemampuan menghitung dan mengunakan rumus yang di pelajari. Setelah postes maka lembar jawaban di berikan skor sesuai dengan ketentuan jika benar diberikan skor 1 dan salah diberikan skor 0 .

Berdasarkan analisis data skortes awal dan tes akhir diperoleh bahwa rata-rata skor pretest adalah 34,10 (skala: 0 -100), sedangkan ratarata skor postest adalah 75,54 (skala 0 -100). Hasil penelitian diperoleh menunjukkan adanya peningkatan dan perbedaan yang signifikan hasil belajar pada materi penyajian data, ukuran penempatan dan ukuran gejala pusat antara pretes dan postes setelah diajarkan melalui model pembelajaran kooperatif tipe STAD. Diperoleh dari skor effect size adalah 3,6., menunjukan adanya pengaruh model pembelajaran kooperatif tipe STAD pada hasil belajar mahasiswa. Peningkatan hasil belajar ini dialami lebih dari $75 \%$ mahasiswa. Ini disebabkan kelompok yang dibentuk dengan memperhatikan kemampuan mahasiswa yang sedang sampai kemampuan yang tinggi.
Berdasarkan hasil perhitungan uji-t, didapatkan bahwa $t_{\text {hitung }}$ sebesar

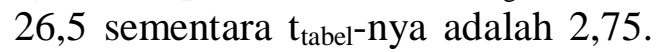
Karena $t_{\text {hitung }}>t_{\text {tabel }}, \quad$ maka keputusannya adalah menerima $\mathrm{Ha}$ dan menolak Ho. Sehingga disimpulkan bahwa terdapat perbedaan hasil belajar mahasiswa sebelum dan setelah dilakukannya pembelajaran melalui model pembelajaran kooperatif tipe STAD pada penyajian data, ukuran penempatan dan ukuran gejala pusat pada mata kuliah statistik dasar.

Dari analisis data diperoleh adanya pengaruh dan peningkatan hasil belajar mahasiswa bukan hanya dipengaruh model pembelajaran kooperatif Tipe STAD tetapi oleh kekompakan kelompok kecil yang saling berkelaborasi membantu teman-teman yang masih kurang memahami materi. Pemilihan dan penggunaan metode penugasan dan diskusi (Slavin, 2010:4), serta penyajian materi dengan bantuan media seperti LCD dan powerpoint juga memberikan kemudahan bagi mahasiswa untuk memahami materi, sehingga dapat meningkatan hasil belajar.

Berdasarkan hasil observasi yang dilakukan terhadap kelas ekperimen yang mendapat pembelajaran model pembelajaran kooperatif tipe STAD yang mengikuti mata kuliah statistika dasar, diperoleh temuan bahwa mahasiswa terlihat lebih aktif dalam beraktivitas dan memiliki semangat yang tinggi dalam menyelesaikan masalah yang diberikan. Kualitas aktivitas proses pembelajaran dari hasil pengamatan cenderung meningkat pada setiap pertemuan. Pada pertemuan pertama, kedua, aktivitas mahasiswa 
cenderung masih pada tahap penyesuaian dengan model pembelajaran yang baru mereka terima, namun pada pertemuan kegita aktifitas mahasiswa terlihat lebih aktif, kreatif dan berani dalam proses pembelajaran di kelas, misalnya keberanian mahasiswa mengajukan pertanyaan dan mengemukakan pendapat. Secara umum, aktivitas selama proses pembelajaran model RT pada materi himpunan, macammacam relasi dan fungsi baik dan sangat positif.

Apabila dilihat dari kesiapan belajar, pada pertemuan ketiga mahasiswa lebih siap untuk belajar dan lebih mudah untuk dikondisikan dibandingkan dengan pertemuan pertama dan kedua. Hal ini dikarenakan mahasiswa sudah mendapatkan gambaran pelaksanaan model pembelajaran kooperatif tipe STAD dan tinggal melanjutkan pembelajaran dari pertemuan sebelumnya dengan cara belajar yang sama.

\section{SIMPULAN DAN SARAN}

Berdasarkan data hasil penelitian, diperoleh terdapat peningkatan hasil belajar mahasiswa sesudah diberikan pembelajaran dengan model pembelajaran kooperatif tipe STAD pada materi penyajian data, ukuran penempatan dan ukuran gejala pusat mata kuliah statistik dasar semester 3 PAPK program studi pendidikan biologi. Dari hasil analisis data statistik terdapat perbedaan yang signifikan hasil belajar sebelum dan sesudah diberikan pembelajaran dengan model pembelajaran kooperatif tipe STAD pada materi penyajian data, ukuran penempatan dan ukuran gejala pusat mata kuliah statistik dasar semester 3 PAPK program studi pendidikan biologi.

Peningkatan hasil belajar mahasiswa dengan model pembelajaran kooperatif tipe STAD seharusnya menggunakan bantuan Lembar kerja mahasiswa, sehingga dapat memudahkan penyampaian materi dan mengurangi kesalahan dalam penyampaian materi serta memudahkan untuk diskusi.

\section{DAFTAR PUSTAKA}

Lie, Anita. (2010). Cooperative Learning. Jakarta: Gramedia.

Rusman. (2011). Model-Model Pembelajaran. Jakarta: Raja Grafindo Persada.

Slavin, Robert E. (2005). Cooperative Learning (Teori, Riset, Praktik). Bandung: Nusa Media.

Slavin, Robert E. (2010). Cooperative Learning. Bandung: Nusa Media.

Soedjadi, R. (2004). PMRI dan KBK dalam Era Otonomi Pendidikan. Buletin PMRI. Edisi III, Janu 2004.Bandung: KPPMT ITB.

Sugiyono. (2011). Metode Penelitian Pendidikan (Pendekatan Kuantitatif, Kualitatif, dan $R \& D)$. Bandung: Alfabeta.

Sugiyono. (2011). Statistika Untuk Penelitian. Bandung: Alfabeta.

Sumarmo, U. (2000).Kecenderungan Pembelajaran Matematika pada Abad 21. Makalah pada Seminar di UNSWAGATI Tanggal $10 \quad$ September 2000.Cirebon. 
Implementasi Model Pembelajaran Kooperatif Tipe STAD 39

Trianto.( 2007). Model Pembelajaran

Terpadu dalam Teori dan
Praktek. Jakarta: Prestasi Pustka Publisher. 